\title{
Cholinesterase and Tyrosinase Inhibitory Potential and Antioxidant Capacity of Lysimachia verticillaris L. and Isolation of the Major Compounds
}

\author{
Lysimachia verticillaris L.'nin Kolinesteraz ve Tirozinaz İnhibitör Etki \\ Potansiyeli ve Antioksidan Kapasitesi ile Ana Bileşiklerinin İzolasyonu
}

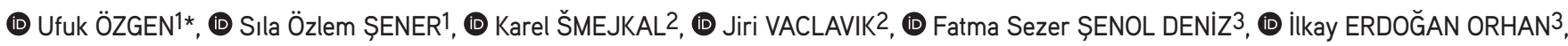 \\ (D) Emil SVAJDLENKA 2 , (D) Ahmet C. GÖREN 4 , (D) Milan ŽEMLIČKA2 \\ 1Karadeniz Technical University Faculty of Pharmacy, Department of Pharmacognosy, Trabzon, Turkey \\ ¿University of Veterinary and Pharmaceutical Sciences Brno, Faculty of Pharmacy, Department of Natural Drugs, Brno, Czechia \\ ${ }^{3}$ Gazi University Faculty of Pharmacy, Department of Pharmacognosy, Ankara, Turkey \\ 4Bezmialem Vakıf University Faculty of Pharmacy, Department of Chemistry, İstanbul, Turkey
}

\section{ABSTRACT}

Objectives: The scope of the present study was to specify the therapeutic potential for neurodegenerative diseases through evaluating cholinesterase and tyrosinase (TYR) inhibitory and antioxidant activity of Lysimachia verticillaris (LV), and to isolate the major compounds considering the most active fraction.

Materials and Methods: The methanol extract (ME) of LV and the chloroform, ethyl acetate (EtOAC), and aqueous fractions obtained from it were used for biological activity and isolation studies. The ME and all fractions were tested for their acetylcholinesterase (AChE), butyrylcholinesterase (BChE), and TYR inhibitory and antioxidant potentials using ELISA microtiter assays. Seven major compounds were isolated from the active EtOAC fraction by semi-preparative high performance liquid chromatography. The structures of the compounds were elucidated by several spectroscopic methods.

Results: Marked AChE inhibitory activity was observed in the EtOAC fraction (6337 $\pm 1.74 \%)$, BChE inhibitory activity in the ME and EtOAC fraction $(85.84 \pm 3.01 \%$ and $83.82 \pm 3.93 \%)$, total phenol content in the EtOAC fraction $(261.59 \pm 3.95 \mathrm{mg}$ equivalent of gallic acid/1 $\mathrm{g}$ of extract) and total flavonoid contents in the EtOAC fraction $(515.54 \pm 2.80 \mathrm{mg}$ equivalent of quercetin $/ 1 \mathrm{~g}$ of extract), and 2,2-diphenyl-1-picrylhydrazyl radical scavenging activity and ferric-reducing antioxidant power values in the aqueous and EtOAC fractions $(92.54 \pm 0.67 \%, 92.11 \pm 0.30 \% ; 2.318 \pm 0.054$, $2.224 \pm 0.091$, respectively). Accordingly, the isolation studies were carried out on the EtOAC fractions. Compounds 1-7 (gallic acid, (+)-catechin, myricetin 3-O-arabinofuranoside, myricetin 3-O- $\alpha$-rhamnopyranoside, quercetin 3-O- $\beta$-glucopyranoside, quercetin 3-0-arabinofuranoside, and quercetin 3-O- $\alpha$-rhamnopyranoside, respectively) were isolated from the active EtOAC fraction.

Conclusion: LV may be a potential herbal source for treatment of neurodegenerative diseases based on its strong antioxidant activity and significant cholinesterase inhibition similar to that of the reference.

Key words: Anticholinesterase, HPLC, isolation, Lysimachia, tyrosinase

ÖZ

Amaç: Bu çalıșmanın amacı, Lysimachia verticillaris'in (LV) kolinesteraz, tirozinaz inhibitör etkisini ve antioksidan aktivitesini değerlendirerek nörodejeneratif hastalıklar için terapötik potansiyelini belirlemek ve en etkili fraksiyondan hareketle ana bileşiklerini izole etmektir.

Gereç ve Yöntemler: Biyolojik aktivite ve izolasyon çalışmaları için LV'nin metanol ekstresinden hareketle kloroform, EtOAC ve sulu fraksiyonları elde edilmiştir. Etkili EtOAC fraksiyonundan, yarı preparatif yüksek performanslı sıvı kromatografisi (YBSK) yöntemi ile 7 ana bileșik izole edilmiştir. İzole edilen bileșiklerin yapıları çeșitli spektroskopik yöntemler kullanılarak aydınlatılmıștır. Metanol ekstresi (ME) ve tüm fraksiyonların asetilkolinesteraz (AChE), butirilkolinesteraz (BChE), tirozinaz inhibitor etkileri ve antioksidan potansiyelleri ELISA yöntemleri kullanılarak belirlenmiștir.

Bulgular: En yüksek AChE inhibitor etki EtOAc fraksiyonunda $(\% 63,37 \pm 1,74)$, en yüksek BChE inhibitör etki ME'de ve etil asetat fraksiyonunda

*Correspondence: E-mail: uozgen@ktu.edu.tr, Phone: +90 4623778828 ORCID-ID: orcid.org/0000-0001-9839-6717

Received: 15.05.2019, Accepted: 05.09.2019

๑Turk J Pharm Sci, Published by Galenos Publishing House. 


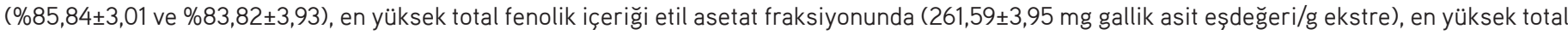
flavonoit içeriği etil asetat fraksiyonunda (515,54 $2,80 \mathrm{mg}$ kersetin eşdeğeri/1 g ekstre) gözlenmiştir. En yüksek 2,2-difenil-1-pikrilhidrazil radikal

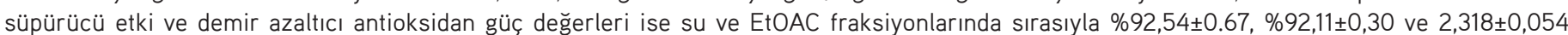
$2,224 \pm 0,091$ olarak belirlenmiștir. Aktivite sonuçlarına dayanarak izolasyon çalıșmalarının etil asetat fraksiyonunda yürütülmesine karar verilmiştir. Etil asetat fraksiyonundan, gallik asit (1), (+) kateşin (2), mirsetin 3-0-arabinofuranozit (3), mirsetin 3-0- $\alpha$-ramnopiranozit (4), kersetin 3-0- $\beta$ glukopiranozit (5), kersetin 3-0-arabinofuranozit (6) ve kersetin 3-0- $\alpha$-ramnopiranozit (7) ana bileșikleri izole edilmiştir.

Sonuç: LV, güçlü antioksidan aktivitesiye sahip olması ve referans bileşiklerle karşılaştırıldığında benzer kolinesteraz inhibitor etki göstermesi nedeniyle nörodejeneratif hastalıkların tedavisi için potansiyel bir bitkisel ilaç kaynağı olabilir.

Anahtar kelimeler: Antikolinesteraz, YBSK, izolasyon, Lysimachia, tirozinaz

\section{INTRODUCTION}

Neurodegenerative diseases such as Alzheimer's disease (AD) and Parkinson's disease (PD), common in the elderly population over the age of 65 , have become serious health problems especially in industrialized countries. Hence, a huge amount of research is being conducted to find new drugs and treatment strategies for these diseases. In this sense, natural products and medicinal herb extracts are attractive sources in the search for novel anti-AD and anti-PD drug candidates. Deficiency in acetylcholine, hydrolyzed by acetylcholinesterase (AChE) and butyrylcholinesterase (BChE), has been proved in the brains of AD patients.' On the other hand, the function of tyrosinase (TYR) is to catalyze the oxidation reaction of tyrosine to melanin, which is linked to hyperpigmentation of skin, occurrence of melanoma, unwanted browning of fruits and vegetables, and dopamine toxicity in PD. ${ }^{2}$

The genus Lysimachia (Primulaceae) is represented by 8 taxa in the Turkish flora. ${ }^{3}$ Lysimachia species, locally known as "karga otu", "adi karga otu", and "altın kamış" in Turkey, have been recorded to be used for expectorant, antipyretic, and wound healing purposes as well as against cough and bronchitis in Anatolian folk medicine. ${ }^{4}$ Lysimachia species contain assorted secondary metabolites including flavonoids, triterpenes, phenolic acids, etc..$^{5-7}$ Moreover, several Lysimachia species have many desirable biological activities such as cytotoxic, hepatoprotective, and vasorelaxant. ${ }^{8-10}$

Based on the information that Lysimachia monnieri is a synonym of Bacopa monnieri, the reputed plant called "brahmi" in Ayurvedic medicine for its strong memory-enhancing effect, we aimed to study the memory-enhancing effect of another species, L. verticillaris. For this purpose, in the current study, AChE, BChE, and TYR inhibitory activity and antioxidant potential including 2,2-diphenyl-1-picrylhydrazyl (DPPH) radical scavenging activity and ferric-reducing antioxidant power (FRAP) were studied in the methanol extract (ME) and all fractions. The EtOAC fraction that showed remarkable anticholinesterase and antioxidant effect was subjected to various chromatographic methods, which gave seven pure compounds (1-7). The structures of the compounds were identified by means of ${ }^{1} \mathrm{H}-\mathrm{NMR}$ and ${ }^{13} \mathrm{C}$-NMR. In addition, the total phenol and flavonoid quantities in the samples were measured spectrophotometrically.

\section{MATERIALS AND METHODS}

\section{Instruments and chemicals}

NMR spectra were obtained on a Varian-600 spectrometer at $600 \mathrm{MHz}$ for ${ }^{1} \mathrm{H}$-NMR and $150 \mathrm{MHz}$ for ${ }^{13} \mathrm{C}$-NMR using $\mathrm{CD}_{3} \mathrm{OD}$ as solvent. An Agilent-1100 series was used for high-performance liquid chromatography (HPLC) studies (Germany). A Unico 4802 ultraviolet (UV)-visible spectrophotometer (USA) was used for antioxidant activity, total phenol, and flavonoid contents studies. A Supelco Ascentis ${ }^{\circledast}$ RP-amide $(250 \times 10 \mathrm{~mm}, 5 \mu \mathrm{m})$ column, HPLC grade acetonitrile and methanol (Scharlau Chemie S.A., Spain), formic acid (Lachema, Brno, CZ), Sephadex LH-20 (Sigma-Aldrich), silica gel 60 (Merck 7734 and Merck 9385), LiChroprep RP-18 (Merck 9303), and silica gel 60 F254 (Merck 5554) were used for the isolation and chromatographic studies.

To measure the enzyme inhibition assays, a 96-well microplate reader (VersaMax Molecular Devices, USA), electric eel AChE (Type-VI-S, EC 3.1.1.7, Sigma), horse serum BChE (EC 3.1.1.8, Sigma), acetylthiocholine iodide and butyrylthiocholine chloride (Sigma, USA), 5,5'-dithio-bis (2-nitrobenzoic acid) (DTNB, Sigma, USA), galantamine (Sigma, USA), TYR (EC 1.14.1.8.1, 30 $\mathrm{U}$, mushroom tyrosinase, Sigma), and L-DOPA were used.

\section{Plant material}

The aerial parts of Lysimachia verticillaris (LV) were gathered in the vicinity of Kafkasör at an altitude of 1300 m (Artvin Province, Turkey). The identification of the plant was performed by Dr. Ufuk Özgen. A voucher specimen (AEF 26311) is deposited at the Herbarium of the Faculty of Pharmacy.

\section{Extraction}

Air-dried and finely powdered samples ( $500 \mathrm{~g}$ ) were extracted with $\mathrm{MeOH}$ ( $2 \mathrm{Lx} 8 \mathrm{~h}$, three times). The combined extracts were evaporated to obtain $74 \mathrm{~g}$ of the crude residue. The ME (73 g) was suspended in an $\mathrm{H}_{2} \mathrm{O}: \mathrm{MeOH}(9: 1)$ mixture and then partitioned with chloroform (300 mLx2) and EtOAc (300 $\mathrm{mLx} 2$ ) successively. The chloroform and EtOAc fractions were evaporated at reduced pressure at $40{ }^{\circ} \mathrm{C}$ and were $15.6 \mathrm{~g}$ and $6.6 \mathrm{~g}$, respectively. The aqueous phase was evaporated to give a residue $(46.3 \mathrm{~g})$. The ME and all fractions obtained from it were employed in the activity assays performed herein.

\section{AChE and BChE inhibitory activities}

The enzyme inhibitory activities were evaluated by a modified version of the method developed by Ellman et al. ${ }^{11,12}$ 


\section{Tyrosinase inhibitory activity}

The modified dopachrome method was used by measuring at $475 \mathrm{~nm}^{13}$ The results were compared with a control consisting of $50 \%$ dimethyl sulfoxide in place of sample.

\section{DPPH radical scavenging activity}

The activities of the samples were detected by Blois' method. ${ }^{14}$ Absorbance was measured at $520 \mathrm{~nm}$.

\section{Ferric-reducing antioxidant power assay}

The FRAP values were determined by the assay described by Oyaizu..$^{15}$ The absorbance was monitored at $700 \mathrm{~nm}$.

\section{Total phenol and flavonoid contents}

Phenolic content of the samples was determined using the Folin-Ciocalteu method. ${ }^{16}$ Absorbance was read at $760 \mathrm{~nm}$.

The total flavonoid content of the samples was measured by aluminum chloride colorimetric method. ${ }^{17}$

\section{Statistical analysis}

The statistical analysis of the enzyme inhibition and antioxidant capacity assays was conducted using Softmax PRO 4.3.2.LS software. The data were expressed as mean \pm scanning electron microscopy. Statistical differences between groups were evaluated by ANOVA (One-Way). Dunnett's multiple comparison tests were used as post hoc tests. $p<0.05$ was considered to be significant $\left({ }^{*} p<0.05 ;{ }^{* *} p<0.01 ;{ }^{* * *} p<0.001,{ }^{* * *} p<0.0001\right)$.

Isolation of the major compounds from LV by combined open column chromatography and semi-preparative HPLC

The EtOAC fraction was applied to column chromatography using a silica gel 60 and $\mathrm{CHCl}_{3}: \mathrm{MeOH}(80: 20 \rightarrow 50: 50)$ solvent system. The subfractions 5-14 combined were subjected to a semi-preparative HPLC column, which yielded seven compounds (1-7) (Figure 1). The flow rate of the solvent was adjusted to $4.0 \mathrm{~mL} / \mathrm{min}$. The mobile phase composition was linear gradient; 0 min: $40 \% \mathrm{MeOH}+60 \%$ formic acid $0.2 \%$ in aqueous solution); $36 \mathrm{~min}: 65 \% \mathrm{MeOH}+35 \%$ formic acid $(0.2 \%$ in aqueous solution). UV-DAD detection was performed at 280 $\mathrm{nm}$. The column temperature was $50^{\circ} \mathrm{C}$.

\section{Structure elucidation of the isolated compounds}

Structure elucidation of the compounds was performed by ${ }^{1} \mathrm{H}-\mathrm{NMR},{ }^{13} \mathrm{C}-\mathrm{NMR}$, and $\mathrm{ESI} / \mathrm{MS}$, which was confirmed finally by comparison of the results with the reported data.

\section{RESULTS}

\section{AChE, BChE, and TYR inhibitory activity}

The ME and all fractions were tested for their enzyme inhibitory activity against $\mathrm{AChE}, \mathrm{BChE}$, and TYR. The aqueous fraction was inactive against both $A C h E$ and $B C h E$, while the $M E$ and EtOAc and chloroform fractions of LV showed high degrees of inhibition against AChE, having $58.21 \pm 3.36 \%, 63.37 \pm 1.74 \%$, and $41.63 \pm 0.45 \%$ inhibition, respectively. Although the ME $(85.84 \pm 3.01 \%)$ and EtOAC fraction of LV $(83.82 \pm 3.93 \%)$ exhibited very high BChE inhibitory activity, similar to galantamine $(86.66 \pm 2.72 \%)$, the chloroform fraction exhibited lower BChE inhibition $(54.65 \pm 0.23 \%)$. All of the fractions and the ME displayed weak inhibition toward TYR, ranging between $14.11 \pm 1.00 \%$ and $16.10 \pm 2.14 \%$ (Table 1).

\section{Antioxidant activity}

In the DPPH radical quenching activity test, the chloroform fraction of LV had moderate activity $(63.66 \pm 0.57 \%)$, whereas high activity against DPPH radical was observed in the aqueous

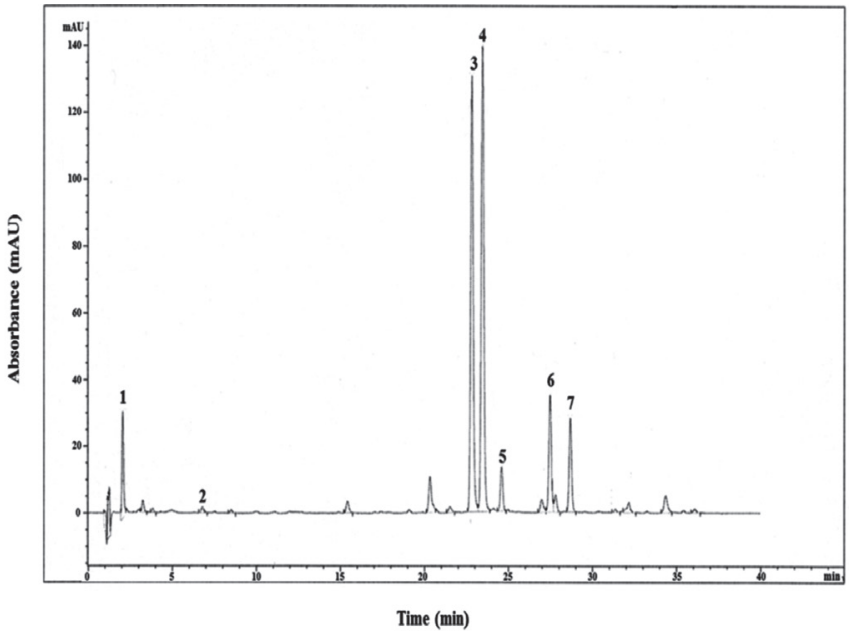

Figure 1. HPLC chromatogram of the EtOAc fraction HPLC: High-performance liquid chromatography, EtOAc: Ethyl acetate, Min: Minute

Table 1. TYR, AChE, and BChE inhibitory activity of the methanol extract and EtOAC, chloroform, and aqueous fractions

\begin{tabular}{|c|c|c|c|}
\hline \multirow{2}{*}{ Samples } & \multicolumn{3}{|c|}{ Inhibitory level $\left(\% \pm \mathrm{SEM}^{\mathrm{a}}\right)$ at $100 \mu \mathrm{g} / \mathrm{mL}$} \\
\hline & TYR & AChE & BChE \\
\hline $\mathrm{MeOH}$ Extract & $14.11 \pm 1.00^{\star \star * \star}$ & $58.21 \pm 3.36^{* *}$ & $85.84 \pm 3.01$ \\
\hline EtOAc Fr. & $16.10 \pm 2.14^{\star \star \star *}$ & $63.37 \pm 1.74^{* *}$ & $83.82 \pm 3.93$ \\
\hline Chloroform Fr. & $15.33 \pm 0.97^{\star \star \star \star}$ & $41.63 \pm 0.45^{\star \star \star \star}$ & $54.65 \pm 0.23^{\star \star \star}$ \\
\hline Aqueous Fr. & $14.31 \pm 0.98^{* * * *}$ & $-\mathrm{b}$ & $-b$ \\
\hline Galantamine $^{c}$ & & $94.48 \pm 3.81$ & $86.66 \pm 2.72$ \\
\hline Kojic acid ${ }^{d}$ & $85.44 \pm 0.14$ & & \\
\hline
\end{tabular}

aStandard error mean, ${ }^{b}$ No inhibition, ${ }^{c}$ Reference for inhibitory activity against AChE and BChE, ${ }^{d}$ Reference for inhibitory activity against tyrosinase, ("p $p<0.05$, " $p<0.01$, " (now" p 0.0001), TYR: Tyrosinase, AChE: Acetylcholinesterase, BChE: Butyrylcholinesterase, EtOAc: Ethyl acetate, SEM: Scanning electron microscopy 
(92.54 $\pm 0.67 \%)$ and EtOAc fractions (92.11 $\pm 0.30 \%)$. On the other hand, the aqueous and EtOAc fractions possessed the highest FRAP values, which are higher than that of quercetin used as the reference (Table 2).

\section{Total phenol and flavonoid contents}

The total phenol contents of the chloroform, EtOAC, and aqueous fractions and ME were stated as gallic acid equivalent (GAE, mg/g extract), while their total flavonoid contents were stated as quercetin equivalent (QUE, mg/g extract). The richest total phenol content belonged to the EtOAC fraction $(261.59 \pm 3.95 \mathrm{mg} / \mathrm{g}$ extract). Similarly, the EtOAc fraction was also found to have the most abundant total flavonoid content $(515.54 \pm 2.80 \mathrm{mg} / \mathrm{g}$ extract) (Table 3 ).

Identification of the compounds isolated from the active EtOAC fraction

Compounds 1-7 were isolated from the active EtOAC fraction (Figure 2); they were isolated from LV for the first time. The NMR data for all compounds are given as ${ }^{1} \mathrm{H}-\mathrm{NMR}(600 \mathrm{MHz}$, $\left.\mathrm{CD}_{3} \mathrm{OD}\right)$ and ${ }^{13} \mathrm{C}-\mathrm{NMR}\left(150 \mathrm{MHz}, \mathrm{CD}_{3} \mathrm{OD}\right)$ :

\section{Compound 1}

Grayish powder. ${ }^{1} \mathrm{H}-\mathrm{NMR}: \delta 6.94(\mathrm{~s}, 2 \mathrm{H}, \mathrm{H}-2$ and $\mathrm{H}-6) .{ }^{13} \mathrm{C}-\mathrm{NMR}$ :

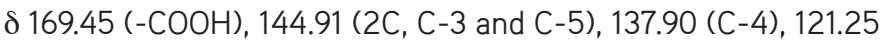
(C-1), 108.84 (2C, C-2 and C-6). NMR data are in total agreement with the data for gallic acid. ${ }^{18}$

\section{Compound 2}

Grayish powder. 'H-NMR: $\delta 6,73(d, 1 \mathrm{H}, \mathrm{J}=2.0 \mathrm{~Hz}, \mathrm{H}-2$ '), $6.65(d$, $\left.1 \mathrm{H}, J=8.1 \mathrm{~Hz}, \mathrm{H}-5^{\prime}\right), 6.62\left(d d, 1 \mathrm{H}, J_{1}=2.0, J_{2}=8.1 \mathrm{~Hz}, \mathrm{H}-6^{\prime}\right), 5.82$ (d, 1H, J=2.4 Hz, H-8), $5.75(d, 1 \mathrm{H}, J=2.4 \mathrm{~Hz}, \mathrm{H}-6), 4.46(d, 1 \mathrm{H}$, $J=7.6 \mathrm{~Hz}, \mathrm{H}-2), 3.87(t d, 1 \mathrm{H}, \mathrm{H}-3), 2.75\left(d d, 1 \mathrm{H}, \mathrm{J}_{1}=5.3, J_{2}=15.9\right.$ $\mathrm{Hz}, \mathrm{H}-4 \mathrm{a}), 2.40$ (dd, 1H, J $\left.=8.2, J_{2}=15.8 \mathrm{~Hz}, \mathrm{H}-4 \mathrm{~b}\right) .{ }^{13} \mathrm{C}-\mathrm{NMR}: \delta$ 156.42 (C-7), 156.16 (C-5), 155.49 (C-9), 144.83 (C-3' or C-4'), 144.80 (C-3' or C-4'), 130.79 (C-1'), 118.59 (C-6'), 114.63 (C-5'), 113.82 (C-2'), 99.37 (C-10), 94.83 (C-8), 94.05 (C-6), 81.43 (C-2),
67.39 (C-3), 27.10 (C-4). NMR data are in total agreement with the data for $(+)$-catechin. ${ }^{19}$

\section{Compound 3}

Yellow powder. ${ }^{1} \mathrm{H}-\mathrm{NMR}$ : $\delta 7.08\left(s, 2 \mathrm{H}, \mathrm{H}-2\right.$ ' and $\left.\mathrm{H}-6{ }^{\prime}\right), 6.38(d, 1 \mathrm{H}$, $J=1.0 \mathrm{~Hz}, \mathrm{H}-8), 6.19$ (d, 1H, J=1.0 Hz, H-6), 5.54 (d, 1H, J=1.1 Hz, $\left.\mathrm{H}-1^{\prime \prime}\right), 4.18-3.32$ (sugar protons, $5 \mathrm{H}, \mathrm{m}, \mathrm{H}-2^{\prime \prime}, \mathrm{H}-3^{\prime \prime}, \mathrm{H}-4^{\prime \prime}, \mathrm{H}-5^{\prime \prime}$ ). ${ }^{13}$ C-NMR: $\delta 177.71$ (C-4), 164.64 (C-7), 161.19 (C-5), 157.15 (C-9), 156.38 (C-2), 145.71 (2C, C3' and C-5'), 136.58 (C-4'), 133.23 (C-3), 119.82 (C-1'), 108.03 (2C, C-2' and C-6'), 107.57 (C-10), 103.85 (C-1"), 98.74 (C-6), 93.52 (C-8), 85.33 (C-4"), 82.00 (C$\left.3^{\prime \prime}\right), 76.74$ (C-2"), 60.40 (C-5"). NMR data are in total agreement with the data for myricetin 3-O- $\alpha$-arabinofuranoside. ${ }^{20}$

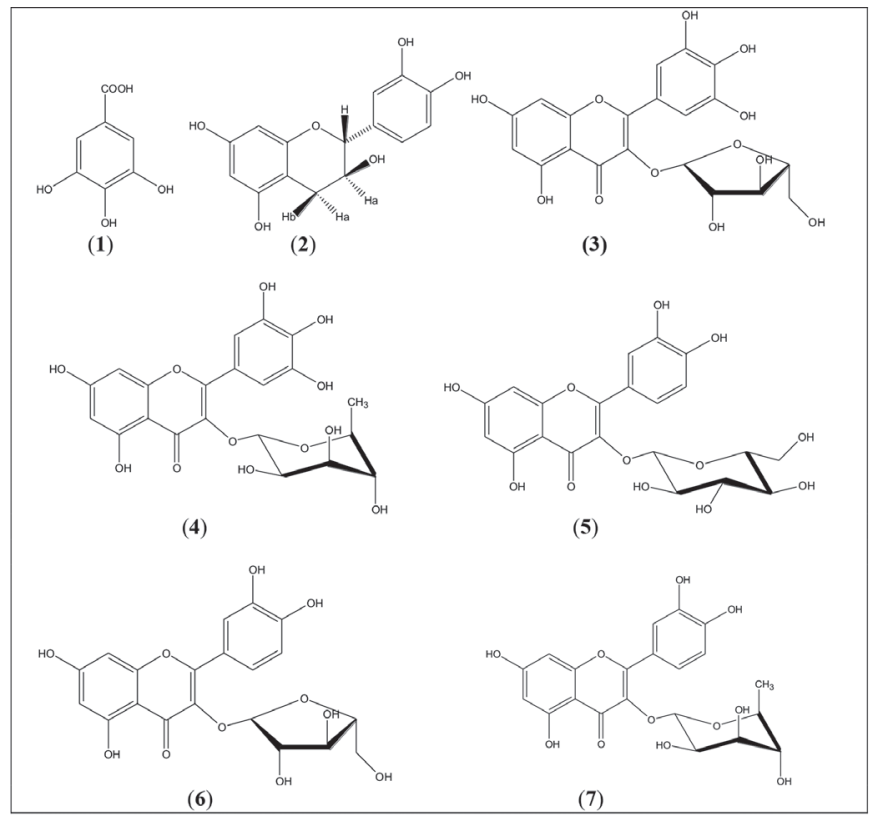

Figure 2. Compounds (1-7) isolated from the EtOAc fraction EtOAc: Ethyl acetate

Table 2. DPPH radical scavenging activity and FRAP of the methanol extract and EtOAc, chloroform, and aqueous fractions at $1000 \mu \mathrm{g} / \mathrm{mL}$

\begin{tabular}{lll} 
Samples & DPPH radical scavenging activity $\left(\% \pm \mathrm{SEM}^{a}\right)$ & FRAP $^{\mathrm{b}}$ \\
\hline MeOH Extract & $82.20 \pm 2.82$ & $0.917 \pm 0.030^{*}$ \\
\hline EtOAC Fr. & $92.11 \pm 0.30$ & $2.224 \pm 0.091$ \\
\hline Chloroform Fr. & $63.66 \pm 0.57^{* *}$ & $0.650 \pm 0.007^{*}$ \\
\hline Aqueous Fr. & $92.54 \pm 0.67$ & $2.318 \pm 0.054$ \\
\hline Quercetin $^{c}$ & $92.75 \pm 0.05$ & $2.090 \pm 0.032$
\end{tabular}

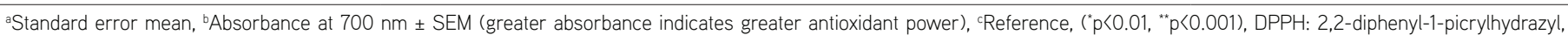
FRAP: Ferric-reducing antioxidant power, EtOAC: Ethyl acetate, SEM: Scanning electron microscopy

Table 3. Total phenol and total flavonoid contents of the methanol extract and EtOAC, chloroform, and aqueous fractions

\begin{tabular}{lll} 
Sample & Total phenol content ${ }^{\mathrm{a}} \pm$ SEM $^{\mathrm{b}}$ & Total flavonoid content $^{\mathrm{c}} \pm$ SEM \\
\hline MeOH Extract & $64.41 \pm 2.26$ & $229.45 \pm 2.80$ \\
\hline EtOAC Fr. & $261.59 \pm 3.95$ & $515.54 \pm 2.80$ \\
\hline Chloroform Fr. & $20.73 \pm 5.53$ & $136.54 \pm 2.52$ \\
\hline Aqueous Fr. & $\mathrm{ND}^{\mathrm{d}}$ & $\mathrm{ND}$ \\
\hline
\end{tabular}

${ }^{a}$ Data expressed in mg equivalent of gallic acid (GAE) to $1 \mathrm{~g}$ of extract, ${ }^{\circ}$ Standard error of the mean, ${ }^{\text {DData }}$ expressed in $\mathrm{mg}$ equivalent of quercetin (QUE) to $1 \mathrm{~g}$ of extract, ${ }^{\mathrm{d}}$ Not determined due to very low solubility, EtOAC: Ethyl acetate, SEM: Scanning electron microscopy 


\section{Compound 4}

Yellow powder. 'H-NMR: $\delta 6.94(s, 2 \mathrm{H}, \mathrm{H}-2$ ' and H-6'), 6.35 (d, $1 \mathrm{H}, J=2.1 \mathrm{~Hz}, \mathrm{H}-8), 6.18(d, 1 \mathrm{H}, J=2.1 \mathrm{~Hz}, \mathrm{H}-6), 5.30(d, 1 \mathrm{H}, J=1.1$ $\left.\mathrm{Hz}, \mathrm{H}-1^{\prime \prime}\right), 4.21\left(t, 1 \mathrm{H}, \mathrm{J}=1.5 \mathrm{~Hz}, \mathrm{H}-2^{\prime \prime}\right), 3.77\left(d d, 1 \mathrm{H}, J_{1}=3.3, J_{2}=9.4\right.$ Hz, H-3"'), 3.50 (m, 1H, H-5"), 3.32 (t, 1H, J=9.6 Hz, H-4"'), 0.95 (d, 3H, J=6.1 Hz, H-6"). ${ }^{13} \mathrm{C}-\mathrm{NMR}: \delta 178.23$ (C-4), 164.47 (C-7), 161.77 (C-5), 158.00 (C-2), 157.07 (C-9), 145.42 (2C, C-3' and C-5'), 136.45 (C-4'), 134.87 (C-3), 120.47 (C-1'), 108.12 (2C, C-6' and C-2'), 104.42 (C-10), 102.18 (C-1"'), 98.36 (C-6), 93.24 (C-8), 71.91 (C-4"), 70.67 (C-2"), 70.60 (C-3"), 70.44 (C-5"), 16.23 (C$6 ")$. NMR data are in total agreement with the data for myricetin 3-O- $\alpha$-rhamnopyranoside. ${ }^{21}$

\section{Compound 5}

Yellow powder. 'H-NMR: $\delta 7.60\left(d, 1 \mathrm{H}, J=2.3 \mathrm{~Hz}, \mathrm{H}-2^{\prime}\right), 7.49$ (dd, $1 \mathrm{H}, \mathrm{J}=2.3,8.8 \mathrm{~Hz}, \mathrm{H}-6$ ') 6.77 (d, 1H, J=8.8 Hz, H-5'), 6.29 (d, 1H, J=1.7 Hz, H-8), $6.10(d, 1 \mathrm{H}, J=2.3 \mathrm{~Hz}), \mathrm{H}-6,5.15(d, 1 \mathrm{H}$, $J=7.7 \mathrm{~Hz}, \mathrm{H}-1^{\prime \prime}$ ), 3.61 (dd, 1H, J =2.4, J $=11.7 \mathrm{~Hz}, \mathrm{H}-6 \mathrm{a}^{\prime \prime}$ ), 3.48 (dd, $\left.1 \mathrm{H}, J_{1}=5.3, J_{2}=11.7 \mathrm{~Hz}, \mathrm{H}-6 \mathrm{~b}^{\prime \prime}\right), 3.38\left(d d, 1 \mathrm{H}, J_{1}=7.7, J_{2}=8.8 \mathrm{~Hz}\right.$, $\left.\mathrm{H}-2^{\prime \prime}\right), 3.32\left(t, 1 \mathrm{H}, \mathrm{J}=8.8 \mathrm{~Hz}, \mathrm{H}-3^{\prime \prime}\right), 3.25$ (dd, $1 \mathrm{H}, \mathrm{J}_{1}=8.8, \mathrm{~J}_{2}=9.9$ $\left.\mathrm{Hz}, \mathrm{H}-4^{\prime \prime}\right), 3.12$ ( $\left.m, 1 \mathrm{H}, \mathrm{H}-5^{\prime \prime}\right) .{ }^{13} \mathrm{C}-\mathrm{NMR}$ : $\delta 178.01$ (C-4), 165.11 (C7), 161.61 (C-5), 157.51 (C-9), 157.08 (C-2), 148.44 (C-3'), 144.49 (C-4'), 134.15 (C-3), 121.73 (C-1'), 121.63 (C-6'), 116.07 (C-2'), 114.56 (C-5'), 104.11 (C-10), $102.87\left(C-1^{\prime \prime}\right), 98.67$ (C-6), 93.42 (C8), 76.96 (C-5"), 76.69 (C-3"), 74.28 (C-2"), 69.77 (C-4"), 61.12 $\left(\mathrm{C}-6^{\prime \prime}\right)$. NMR data are in agreement with the data for quercetin 3-O- $\beta$-glucopyranoside. ${ }^{22}$

\section{Compound 6}

Yellow powder. 'H-NMR: $\delta 7.43(d, 1 \mathrm{H}, \mathrm{J}=1.8 \mathrm{~Hz}, \mathrm{H}-2$ ') 7.40 (dd, $\left.1 \mathrm{H}, \mathrm{J}_{1}=2.1, \mathrm{~J}_{2}=8.5 \mathrm{~Hz}, \mathrm{H}-6^{\prime}\right), 6.80\left(d, 1 \mathrm{H}, \mathrm{J}=8.3 \mathrm{~Hz}, \mathrm{H}-5^{\prime}\right), 6.30$ (s, $1 \mathrm{H}, \mathrm{H}-8), 6.10(d, 1 \mathrm{H}, \mathrm{J}=2.4 \mathrm{~Hz}, \mathrm{H}-6), 5.37$ (s, 1H, H-1"), $4.23(d, 1 \mathrm{H}$, $\left.J=2.3 \mathrm{~Hz}, \mathrm{H}-2^{\prime \prime}\right), 3.81\left(m, 1 \mathrm{H}, \mathrm{H}-3^{\prime \prime}\right), 3.77\left(m, 1 \mathrm{H}, \mathrm{H}-4^{\prime \prime}\right), 3.40(m$, $\left.2 \mathrm{H}, \mathrm{H}-5^{\prime \prime}\right) .{ }^{13} \mathrm{C}-\mathrm{NMR}: \delta 178.54(\mathrm{C}-4), 164.80$ (C-7), $161.64(\mathrm{C}-5)$, 157.89 (C-2), 157.15 (C-9), 148.43 (C-4'), 144.94 (C-3'), 133.45 (C-3), 121.65 (C-1'), 121.52 (C-6'), 115.38 (C-2'), 114.99 (C-5'), 108.07(C1"), 104.12 (C-10), 98.49 (C-6), 93.36 (C-8), 86.57 (C-4"), 81.87 (C2"), 77.24 (C-3"), 61.09 (C-5"). NMR data are in total agreement with the data for quercetin 3-O- $\alpha$-arabinofuranoside. ${ }^{20}$

\section{Compound 7}

Yellow powder. 'H-NMR: $\delta 7.24(d, 1 \mathrm{H}, \mathrm{J}=1.8 \mathrm{~Hz}, \mathrm{H}-2$ '), 7.21 (dd, $\left.1 \mathrm{H}, \mathrm{J}_{1}=1.8, \mathrm{~J}_{2}=8.2 \mathrm{~Hz}, \mathrm{H}-6{ }^{\prime}\right), 6.82\left(d, 1 \mathrm{H}, \mathrm{J}=8.2 \mathrm{~Hz}, \mathrm{H}-5^{\prime}\right), 6.28$ (s, $1 \mathrm{H}, \mathrm{H}-8), 6.11(d, 1 \mathrm{H}, \mathrm{J}=1.2 \mathrm{~Hz}, \mathrm{H}-6), 5.25\left(d, 1 \mathrm{H}, \mathrm{J}=1.2 \mathrm{~Hz}, \mathrm{H}-1^{\prime \prime}\right)$, $4.12\left(d, 1 \mathrm{H}, \mathrm{J}=1.1 \mathrm{~Hz}, \mathrm{H}-2^{\prime \prime}\right), 3.65$ (dd, 1H, J=2.9, J $\left.=9.4 \mathrm{~Hz}, \mathrm{H}-3^{\prime \prime}\right)$, $3.32\left(m, 1 \mathrm{H}, \mathrm{H}-5^{\prime \prime}\right), 3.24\left(d, 1 \mathrm{H}, \mathrm{J}=9.4 \mathrm{~Hz}, \mathrm{H}-4^{\prime \prime}\right), 0.84(d, 3 \mathrm{H}$, $\left.J=6.4 \mathrm{~Hz}, \mathrm{H}-6{ }^{\prime \prime}\right) .{ }^{13} \mathrm{C}-\mathrm{NMR}: \delta 178.21$ (C-4), 164.65 (C-7), 161.76 (C-5), 157.89 (C-2), 157.11 (C-9), 148.39 (C-4'), 144.99 (C-3'), 134.78 (C-3), 121.52 (C-1'), 121.42 (C-6'), 115.50 (C-5'), 114.95 (C2'), 104.41 (C-10), 102.11 (C-1"'), 98.45 (C-6), 93.33 (C-8), 71.82 (C-4"), 70.67 (C-3"), 70.61 (C-2"), 70.47 (C-5"), 16.21 (C-6"). NMR data are in total agreement with the data for quercetin 3-O- $\alpha$-rhamnopyranoside..$^{18-21}$

\section{DISCUSSION}

Since ancient times, plants have served as one of the most important sources of medicines. Approximately 500 species are known to be used as folk medicine in Anatolia.

Many desirable biological activities such as analgesic, anticholecystitis, cholagogic, cytotoxic, hepatoprotective, and vasorelaxant activity of Lysimachia species used traditionally for expectorant, antipyretic, and wound healing purposes in Turkey are reported. ${ }^{4-10}$

Taking the folkloric and modern use of $L$. monnieri for memory enhancement into account, we designed the current study, which was the first on the neuroprotective effect of any Lysimachia species. Confirming its folkloric use, the ME as well as the EtOAC and chloroform fractions of LV inhibited AChE and BChE effectively. Among them, we chose the EtOAc fraction for further study due to its high cholinesterase inhibitory and antioxidant effects. Our phytochemical studies in order to identify substances found in the fraction led to the isolation of seven phenolic compounds (1-7) from the plant for the first time. The compounds were characterized as gallic acid (1), (+)-catechin (2), myricetin 3-O- $\alpha$-arabinofuranoside (3), myricetin 3-O- $\alpha$-rhamnopyranoside (4), quercetin 3-O- $\beta$ glucopyranoside (5), quercetin 3-O- $\alpha$-arabinofuranoside (6), and quercetin 3-O- $\alpha$-rhamnopyranoside (7).

Previous phytochemical studies on other Lysimachia species showed the presence of secondary metabolites including flavonoids, triterpenes, phenolic acids, etc. ${ }^{5-7}$ According to these studies, Lysimachia species have rich phenolic compounds such as gentisic acid, caffeic acid, chlorogenic acid, $p$-coumaric acid, apigenin, luteolin, myricetin, quercetin, kaempferol, isorhamnetin, quercetin 3-O-glucoside, quercetin 3-O-rutinoside, myricetin 3-O-glucoside, myricetin 3-O-rhamnoside, eriodictyol 7-O-glucoside, vitexin, and isovitexin. ${ }^{5-7}$ Phenolic compounds are known to be generally responsible for the antioxidant capacity of plant extract. For instance, among them, gallic acid, $(+)$-catechin, myricetin3-O-arabinofuranoside, and myricetin-3-O-rhamnoside have been demonstrated to be well-known compounds with remarkable antioxidant potential. ${ }^{23-25}$ The antioxidant activity, anti-inflammatory, antinociceptive, and antipyretic activities of quercetin $3-O-\beta$-arabinopyranoside and quercetin $3-O-\alpha-L-$ rhamnopyranoside have been proven by Ramzi et al. ${ }^{26}$ The DPPH assay, which determines the scavenging ability of antioxidants against stable radical DPPH., is applied as a valid and practical assay, while the FRAP assay is based on the determination of the antioxidant capacity of foods, beverages, and other nutritional supplements rich in polyphenols via their ferric reducing ability. ${ }^{27,28}$ It is a simple, automated test to measure antioxidant capacity. It should be noted that the high antioxidant activity of the EtOAC fraction is strongly correlated with its richest total phenol and flavonoid content and the isolated compounds (1-7) are the major contributors to the marked antioxidant activity of the plant.

On the other hand, flavonoid derivatives have been known to exert strong cholinesterase inhibitory effects. ${ }^{29}$ Many 
researchers have so far pointed out various flavonoids to be responsible for the potent cholinesterase inhibitory capacity of plant extracts. For example, the flavonoid fraction obtained from the fern Dryopteris erythrosora that contained gliricidin 7-O-hexoside, apigenin7-O-glucoside, quercetin 7-O-rutinoside, quercetin 7-O-galactoside, kaempferol 7-O-gentiobioside, kaempferol 3-O-rutinoside, myricetin 3-O-rhamnoside, and quercitrin exhibited strong AChE inhibition over $90 \%$ in dosedependent manner. ${ }^{30}$

Some studies showed that the isolated compounds (+)-catechin, myricetin 3-O-arabinofuranoside, quercetin 3-O- $\beta$-glucopyranoside, quercetin 3-O-arabinofuranoside, and quercetin 3-O- $\alpha$-rhamnopyranoside exhibited an active inhibitory effect against the AChE enzyme as well as strong antioxidative activity. ${ }^{31,32}$ Moreover, gallic acid is well known as a powerful antioxidant to remedy DNA damage due to oxidative stress. ${ }^{33}$

In our previous study, ${ }^{17}$ we reported quercetin with a significant AChE and BChE inhibitory effect in a competitive manner, which was shown to bind with hydrogen bonds to important amino acid residues at the anionic site of AChE. Recently, Ado et al. ${ }^{34}$ demonstrated the presence of many flavonoid derivatives, i.e. catechin, quercetin pentoside, quercetin hexoside, etc. in the AChE-inhibiting fraction of Cynometra cauliflora leaves. In fact, an AChE inhibitory effect of $(+)$-catechin isolated from Canarium patentinervium was described at low level $(>100 \mu \mathrm{g} /$ $\mathrm{mL}){ }^{35}$ Nevertheless, other flavonoid derivatives isolated from LV herein could be suggested to contribute to some extent to the cholinesterase inhibitory effect of the plant as Russo et al. ${ }^{35}$ demonstrated a strong correlation between flavonoids and cholinesterase inhibition through calculation of Pearson correlation.

Actually, it should be also noted that the occurrence of marked cholinesterase inhibitory activity as well as antioxidant activity might also be due to a synergistic action of the flavonoids present in the extract, because in many cases flavonoids have been shown to exert synergistic or additive effects, whereas sometimes antagonism occurs. ${ }^{36-38}$ This is because the antioxidant activity of green tea, grape seed, and lettuce extracts was shown to increase after the addition of quercetin via acting synergistically, while catechins were proven to be responsible for synergism in green tea regarding its antioxidant activity, which might the case in the present study as well. ${ }^{37,38}$

According to previous bioactivity studies, various Lysimachia species such as Lysimachia laka, Lysimachia punctata, Lysimachia foenum-graecum, Lysimachia clethroides, and Lysimachia vulgaris have potent antioxidant capacity. ${ }^{39-43}$ There are limited studies about the cholinesterase inhibitory activity of Lysimachia species. One study showed that Lysimachia christinae was inactive on AChE. ${ }^{4}$

The results of the present study showed that the EtOAc fraction had the highest total phenol and flavonoid content. This may explain why the highest enzyme inhibitor effect was observed on the EtOAC fraction. The total flavonoid content of ME extract was high. The high flavonoid content and other minor compounds of ME extract may be responsible for the similar enzyme inhibitor effect compared with the EtOAc fraction. Although the aqueous fraction has high antioxidant activity, no enzyme inhibitor effect of the aqueous fraction was observed. Furthermore, no total phenol or flavonoid content of the aqueous fraction was detected. The high antioxidant activity of the aqueous fraction may be based on the other compounds, which have no cholinesterase inhibitory effect.

\section{CONCLUSION}

The results obtained from the present study demonstrated that the ME and EtOAc fraction of the aerial parts of LV have strong AChE and BChE inhibitory effects, providing scientific justification for its use in folk medicine. The compounds mentioned herein have been isolated from LV for the first time. The current study is the very first on phytochemistry and neuroprotective effects through the cholinesterase and TYR inhibitory activity of LV. The phenolic compounds we isolated (1-7) may be responsible for the anticholinesterase and antioxidant activities.

\section{ACKNOWLEDGEMENT}

F. Sezer Şenol and Sıla Özlem Şener would like to acknowledge the scholarship during their postgraduate program provided by the Scientific and Technological Research Council of Turkey (TÜBITAK). Also, Prof. Dr. Ufuk Özgen and Sıla Özlem Şener would like to acknowledge the financial support provided by the Council of Higher Education.

Conflicts of interest: No conflict of interest was declared by the authors. The authors alone are responsible for the content and writing of the paper.

\section{REFERENCES}

1. Orhan IE. Current concepts on selected plant secondary metabolites with promising inhibitory effects against enzymes linked to Alzheimer's disease. Curr Med Chem. 2012;19:2252-2261.

2. Mendes E, Perry MJ, Francisco AP. Design and discovery of mushroom tyrosinase inhibitors and their therapeutic applications. Expert Opin Drug Disc. 2014;9:533-554.

3. Terzioglu S, Karaer F. An Alien Species New to the Flora of Turkey. Lysimachia japonica Thunb. (Primulaceae) Turk J Bot. 2009;33:123-126.

4. Kızılarslan Ç, Özhatay N. Wild plants used as medicinal purpose in the south part of İzmit (Northwest Turkey). Turk J Med Sci. 2012;9:199-218.

5. Tóth A, Riethmüller E, Alberti Á, Végh K, Kéry Á. Comparative phytochemical screening of phenoloids in Lysimachia species. Eur Chem Bull. 2012;1:27-30.

6. Marr KL, Bohm BA, Cooke C, Gunning P. Flavonoids of Hawaiian endemic Lysimachia in honour of professor $\mathrm{GH}$ Neil Towers $75^{\text {th }}$ birthday. Phytochemistry. 1998;49:553-557.

7. Hanganu D, Olah NK, Mocan A, Vlase L, Benedec D, Raita O, Toma CC. Comparative polyphenolic content and antioxidant activities of two Romanian Lysimachia species. Studies. Rev Chim. 2016;67:227-231.

8. Podolak I, Koczurkiewicz P, Michalik M, Galanty A, Zajdel P, Janeczko Z. A new cytotoxic triterpene saponin from Lysimachia nummularia $\mathrm{L}$. Carbohydrate Res. 2013;375:16-20. 
9. Wang J, Zhang Y, Zhang Y, Cui Y, Liu J, Zhang B. Protective effect of Lysimachia christinae against acute alcohol-induced liver injury in mice. Biosci Trends. 2012; 6:89-97.

10. Lee JO, Chang K, Kim CY, Jung SH, Lee SW, Oak MH. Lysimachia clethroides extract promote vascular relaxation via endotheliumdependent mechanism. J Cardiovasc Pharmacol. 2010;55:481-488.

11. Ellman GL, Courtney KD, Andres V, Featherstone RM. A new and rapidcolorimetric determination of acetylcholinesterase activity. Biochem Pharmacol. 1961;7:88-95.

12. Khan MTH, Orhan I, Senol FS, Kartal M, Sener B, Dvorská M, Smejkal K, Slapetová T. Cholinesterase inhibitory activities of some flavonoid derivatives and chosen xanthone and their molecular docking studies. Chem-Biol Interact. 2009;181:383-389.

13. Masuda T, Yamashita D, Takeda Y, Yonemori S. Screening for tyrosinase inhibitors among extracts of seashore plants and identification of potent inhibitors from Garcinia subelliptica. Biosci Biotechnol Biochem. 2005;69:197-201.

14. Blois MS. Antioxidant determinations by the use of a stable free radical. Nature. 1958;181:1199-1200.

15. Oyaizu M. Studies on products of browning reactions-antioxidative activities of products of browning reaction prepared from glucosamine. Jpn J Nutr. 1986;44:307-315.

16. Singleton VL, Rossi Jr. JA. Colorimetry of total phenolics withphosphomolibdic-phosphotungtic acid reagents. Am J Enol Viticult. 1965;16:144-158

17. Woisky R, Salatino A. Analysis of propolis: some parameters and procedures for chemical quality control. J Apicol Res. 1998;37:99-105.

18. Eldashan OA. Isolation and structure elucidation of phenolic compounds of carob leaves grown in Egypt. Curr Res J Biol Sci. 2011;3:52-55.

19. Adrienne LD, Ya C, Alan PD, Lewis JR. ${ }^{1} \mathrm{H}$ and ${ }^{13} \mathrm{C}$ NMR assignments of some green tea polyphenols. Magnetic Res Chem. 1996;34:887-890.

20. Ek S, Kartimo H, Mattila S, Tolonen A. Characterization of phenolic compounds from Lingonberry (Vaccinium vitis-idaeae). J Agric Food Chem. 2006;54:9834-9842.

21. Aderogba MA, Ndhlala AR, Rengasamy KRR, Van Staden J. Antimicrobial and selected in vitro enzyme inhibitory effects of leaf extracts, flavonols and indole alkaloids isolated from Croton menyharthii. Molecules. 2013;18:12633-12644

22. Ko JH, Kim BG, Kim JH, Kim H, Lim CE, Lim J, Lee C, Lim Y, Ahn, JH. Four glucosyltransferases from rice: cDNA cloning, expression, and characterization. J Plant Physiology. 2008;165:435-444.

23. Mansouri A, Embarek G, Kokkalou E, Kefalas P. Phenolic profile and antioxidant activity of the Algerian ripe date palm fruit (Phoenix dactylifera). Food Chem. 2005;89:411-420.

24. Verma AK, Rajkumar V, Banerjee R, Biswas S, Das AK. Guava (Psidium guajava L.) Powder as an Antioxidant Dietary Fibre in Sheep Meat Nuggets. Asian-Australas J Anim Sci. 2013;26:886-895.

25. Okoth DA, Chenia HY, Koorbanally NA. Antibacterial and antioxidant activities of flavonoids from Lannea alata (Engl.) Engl. (Anacardiaceae). Phytochem Lett. 2013;6:476-481.

26. Ramzi AA, Mothana MS, Al-Said AJ, Al-Rehaily TM, Thabet NA, Awad M, Lalk UL. Anti-inflammatory, antinociceptive, antipyretic and antioxidant activities and phenolic constituents from Loranthus regularis Steud. ex Sprague. Food Chem. 2012;130:344-349.

27. Sun LJ, Zhang JB, Lu XY, Zhang, LY, Zhang YL. Evaluation to the antioxidant activity of total flavonoids extract from persimmon (Diospyros kaki L.) leaves. Food Chem Toxicol. 2011;49:2689-2696.
28. Cao J, Xia X, Chen X, Xiao J, Wang Q. Characterization of flavonoids from Dryopteris erythrosora and evaluation of their antioxidant, anticancer and acetylcholinesterase inhibition activities. Food Chem Toxicol. 2013;51:242-250.

29. Orhan IE. Implications of some selected flavonoids towards Alzheimer's disease with the emphasis on cholinesterase inhibition and their bioproduction by metabolic engineering. Curr Pharm Biotechnol. 2014;15:352-361.

30. Anand P, Singh B. Flavonoids as lead compounds modulating the enzyme targets in Alzheimer's disease. Med Chem Res. 2013;22:30613075 .

31. Odontuya G. Anti-oxidative, acetylcholinesterase and pancreatic lipase inhibitory activities of compounds from Dasiphora fruticosa, Myricaria alopecuroides and Sedum hybridum. Mongolian Journal of Chemistry. 2017;43:42-49.

32. Gasca CA, Castillo WO, Takahashi CS, Fagg CW, Magalhães PO, Fonseca-Bazzo YM, Silveira D. Assessment of anti-cholinesterase activity and cytotoxicity of cagaita (Eugenia dysenterica) leaves. Food and Chemical Toxicology. 2017;109:996-1002.

33. Farhoosh R, Nyströmm L. Antioxidant potency of gallic acid, methyl gallate and their combinations in sunflower oil triacylglycerols at high temperature. Food Chem. 2018;244:29-35.

34. Ado MA, Abas F, Ismail IS, Ghazali HM, Shaari K. Chemical profile and antiacetylcholinesterase, antityrosinase, antioxidant and $\alpha$-glucosidase inhibitory activity of Cynometra cauliflora L. leaves. J Sci Food Agric. 2015;95:635-642.

35. Russo D, Valentão P, Andrade PB, Fernandez EC, Milella L. Evaluation of antioxidant, antidiabetic and anticholinesterase activities of Smallanthus sonchifolius landraces and correlation with their phytochemical profiles. Int J Mol Sci. 2015;16:17696-71718.

36. Wang S, Wang D, Liu Z. Synergistic, additive and antagonistic effects of Potentilla fruticosa combined with EGb761 on antioxidant capacities and the possible mechanism. Ind Crops Prods. 2015;67:227-238.

37. Altunkaya A, Gökmen V, Skibsted LH. PH dependent antioxidant activity of lettuce (L. sativa) and synergism with added phenolic antioxidants. Food Chem. 2016;190:25-32.

38. Colon M, Nerín C. Synergistic, antagonistic and additive interactions of green tea polyphenols. Eur Food Res Technol. 2015;242:211-220.

39. Gupta S, Sarma S, Mao AA, Seal T. Antioxidant activity of different parts of Lysimachia laxa and Gymnocladus assamicus, a comparison using three different solvent extraction systems. J Chem Pharm Res. 2013;5:33-40.

40. Toth A, Toth G, Kery A. Polyphenol composition and antioxidant capacity of three Lysimachia species. Nat Prod Commun. 2014;9:1473-1478.

41. Li HY, Hao ZB, Wang XL, Huang L, Li JP. Antioxidant activities of extracts and fractions from Lysimachia foenum-graecum Hance. Bioresour Technol. 2009;100:970-974.

42. Wei JF, Zhang ZJ, Cui LL, Kang WY. Flavonoids in different parts of Lysimachia clethroides duby extracted by ionic liquid: analysis by HPLC and antioxidant activity assay. J Chem. 2017;2017:1-10.

43. Yildirim AB, Guner B, Karakas FP, Turker AU. Evaluation of antibacterial, antitumor, antioxidant activities and phenolic constituents of field-grown and in vitro-grown Lysimachia vulgaris $\mathrm{L}$. Afr J Tradit Complement Altern Med. 2017;14:177-187.

44. Kaufmann D, Kaur Dogra A, Tahrani A, Herrmann F, Wink M. Extracts from traditional Chinese medicinal plants inhibit acetylcholinesterase, a known Alzheimer's disease target. Molecules. 2016; 21:1161-1177. 